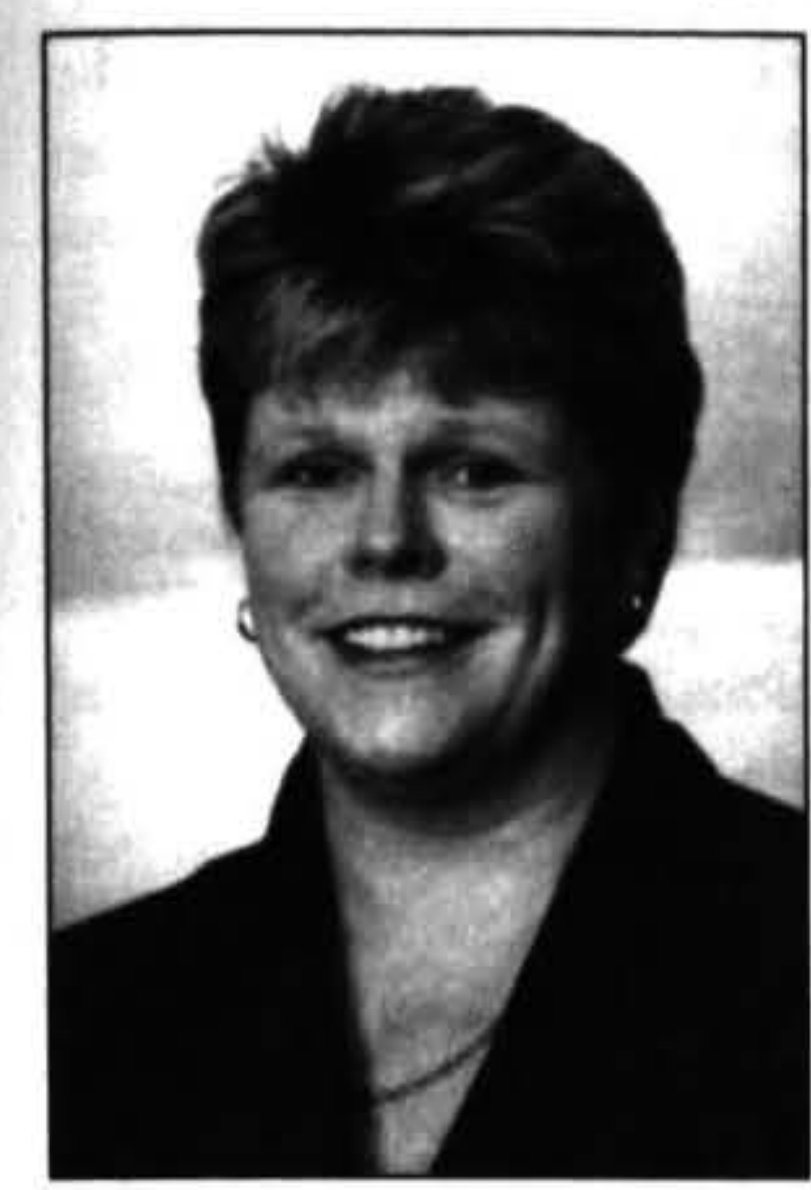

\title{
WORKFORCE DEVELOPMENT: THE LATEST SILVER BULLET?
}

\author{
Nicky Murray \\ CareerForce, Christchurch
}

\begin{abstract}
The term 'Workforce Development' is used with increasing frequency by policy makers, academics and labour market practitioners. On the surface, it is a relatively unproblematic term, yet closer investigation suggests that it is often used as a 'catch-all' phrase, which may have quite different meanings and implications, depending upon the user and the context. In this exploratory paper. I first trace the genesis of the term, noting its theoretical underpinnings in systems thinking. I then discuss some of the drivers behind the evolution of the concept of Workforce Development. and examine why it appears to have supplanted notions of workforce or manpower 'planning'. Using the health and disability sector as a case study, I highlight some of the differences in how the term is used, and discuss the implications. Finally. I ask if the use of a new term, reflecting a presumably significant shift in wavs of thinking about the 'workforce', translates into actions that do, in fact, 'develop' that workforce.
\end{abstract}

\section{Introduction}

My interest in this topic has been sparked by the fact that my last two jobs have had as part of their titles: 'Workforce Development'. I was previously a Workforce Development Co-ordinator for a regional economic development agency and currently have a Workforce Development and Research role with an industry training organisation. In each case, the titles have to varying degrees been both descriptive and aspirational, and given the breadth of activities able to be subsumed under the title, open to flexible interpretation. My aim in this exploratory paper is to tease out some of the ambiguities contained within the term 'Workforce Development' and to hopefully begin some debate that will result in greater clarity.

The term 'Workforce Development' is used with increasing frequency by policy makers, academics and practitioners. On the surface, it is a relatively unproblematic term, yet closer investigation suggests that it is often used as a "catch-all' phrase, which may have quite different meanings and implications, depending upon the user and the context. As Roche (2002) argues:

The term "Workforce Development" is a broad one used to encapsulate a number of key factors pertaining to individuals, the organisations within which they operate and the systems that surround them. It is not always immediately clear what workforce development means, what it includes (and excludes). who it involves, why it is important, and in what ways is it different to the traditional notion of education and training (Roche, 2002:4).

The elasticity of the term can be viewed in four intersecting ways:

Temporal: Workforce Development may be used to refer to: education and training for the existing workforce, ways of recruiting and retaining the required workforce in the short-term, or long-term workforce planning.

Capacity versus Capability: Workforce Development discussions may focus on: the numbers of workers required, or the skill levels required. These skills may be completely new, evolution of existing skills, or require significant upskilling. Conversely, changes in work practices, technology or legislation may effectively deskill parts of jobs.

Level of Workforce Development: Workforce Development may be thought of as occurring at different levels: the individual, the organisation, the sector, and the industry.

Responsibility for Workforce Development: This may also be placed with different (or multiple) levels: the individual, the employer/organisation, sectoral/industry bodies, unions, and government bodies.

Naturally, most workforce development plans/ programmes/groups focus on more than one (and in some cases, on nearly all) of the above dimensions. But understanding the multi-faceted nature of the term helps to shed light on the nature of the fundamental drivers for the conceptualisation, development and execution of any given Workforce Development initiative. 


\section{The Evolution of Workforce Development}

Jacobs and Hawley (2005) describe the emergence of the term Workforce Development. In the United States, it has been used to describe youth vocational education, social welfare programmes or regional economic development initiatives. It is also used in adult education and human resources. In the United Kingdom, it was most closely associated with education and training agencies, but has now extended to many sectors such as health and local government. Jacobs and Hawley (2005) argue that the attraction of the term is that it provides enough breadth to incorporate the understanding that none of the aforementioned activities occur in isolation; that the success of any program or initiative is intimately connected to its interface with the surrounding systems.

As suggested by the above statement, the theoretical backdrop to Workforce Development is found in "systems thinking”. The systems approach developed from the mid20th century as a 'major alternative to the reductionist and disciplines-bound mainstream in social science' (Barton, Emery, Flood, Selsky and Wolstenholme (2004: 4). Systems thinking has evolved from the initial 'closed', structural-functionalist perspectives, where the key premise was that [s]ystems are made up of sets of components that work together for the overall objective of the whole' (Churchman, 1968: I1), to a more 'open' understanding of systems. In 1990, Peter Senge's The Fifth Discipline reintroduced systems thinking to the mainstream. Senge's definition emphasised the complexity and emergent aspects of systems:

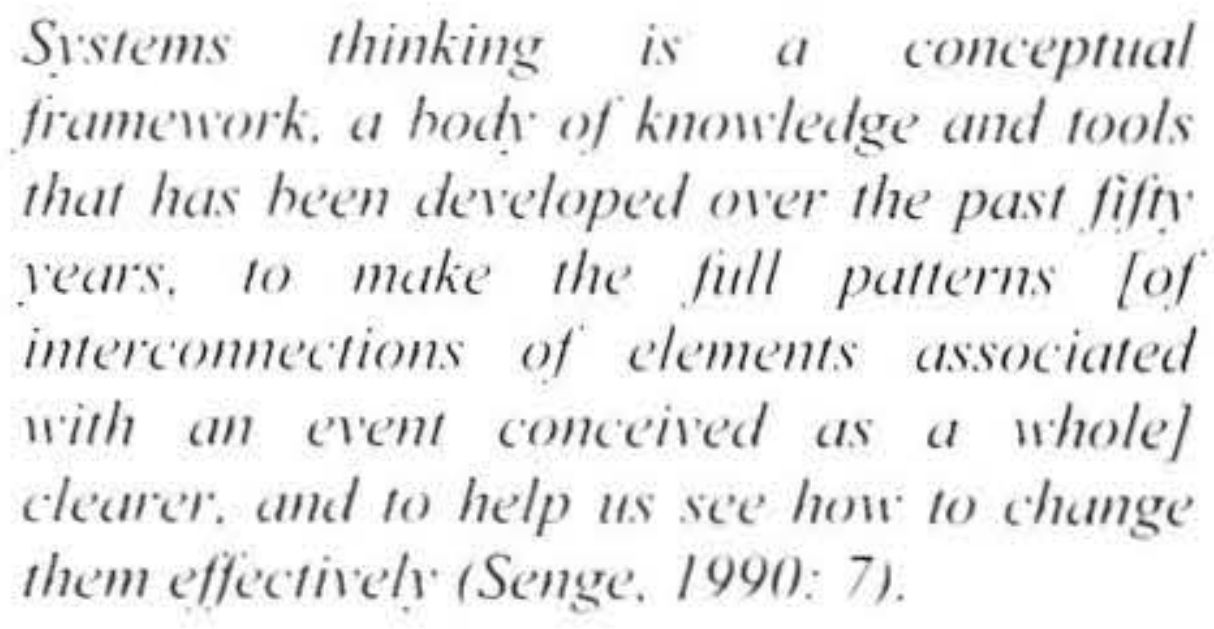

Jacobs and Hawley (2005) identify five drivers for the increasing awareness of the interconnectedness of systems that has made the notion of Workforce Development so appealing. A summary of these drivers and their connection to Workforce Development is presented in Table 1.

\section{From Workforce Planning to Workforce Development: Some Theoretical Underpinnings}

It is important to acknowledge that the nature and impact of all of the drivers shown above are part of a wider theoretical debate. The Fordist/post-Fordist debate is the prevailing means of understanding the nature of the changes to, or transformation of, modern capitalism, and I now briefly outline the parameters of this debate (see Murray [2004] for a fuller discussion).
Table 1: Drivers for workforce development (adapted from Jacobs and Hawley, 2005).

\begin{tabular}{|c|c|}
\hline Driver & $\begin{array}{l}\text { Examples of Impact on Workforce } \\
\text { Development }\end{array}$ \\
\hline Globalisation & $\begin{array}{l}\text { - Connectedness of global } \\
\text { markets, e.g. development of } \\
\text { internationally recognised } \\
\text { standards } \\
\text { - Global competition has lead to } \\
\text { an increased emphasis on } \\
\text { upskilling the current workforce } \\
\text { - In this context, Workforce } \\
\text { Development becomes a 'critical } \\
\text { part of a broader economic } \\
\text { development strategy' (p.6) }\end{array}$ \\
\hline Technology & $\begin{array}{l}\text { - Impacts on human capital } \\
\text { development } \\
\text { - Intersection between technology, } \\
\text { labour and productivity } \\
\text { - Impacts on time/space barriers } \\
\text { - Role of technology in learning }\end{array}$ \\
\hline $\begin{array}{l}\text { 'New' } \\
\text { economy }\end{array}$ & $\begin{array}{l}\text { - Predominance of the 'market' } \\
\text { model } \\
\text { - Casualisation of the workforce } \\
\text { - } \text { New/flexible job classifications } \\
\text { - But much growth has occurred in } \\
\text { low skill service sector jobs }\end{array}$ \\
\hline $\begin{array}{l}\text { Political } \\
\text { changes }\end{array}$ & $\begin{array}{l}\text { Emphasis on contractual models } \\
\text { of service delivery } \\
\text { - Substantial changes in national } \\
\text { training systems }\end{array}$ \\
\hline $\begin{array}{l}\text { Demographic } \\
\text { changes }\end{array}$ & $\begin{array}{l}\text { Retirement of the baby-boomers } \\
\text { - reduction of workforce size } \\
\text { - Adequacy of training and } \\
\text { educational opportunities for the } \\
\text { Generation Y cohort }\end{array}$ \\
\hline
\end{tabular}

\section{Fordism}

Fordism is an attempt by predominantly left-wing and Marxist thinkers to explain advanced capitalist society. It applied the concept of the 'assembly-line' form of manufacturing pioneered by Henry Ford to the production process in general. Ford took the 'scientific management' principles of F.W. Taylor and used them to revolutionise the manufacture of cars. These principles included the breaking down of the production process into its constituent parts, and examining these to find the simplest and most efficient way of carrying them out. This resulted in a series of tasks that could be carried out by less skilled and therefore cheaper labour. The 'conception' and 'execution' of the process were also separated, with management holding the knowledge and control, instead of skilled craft workers who were previously able to carry out the whole job. Fordism was much more than a description of the production process, however. The meaning of term was broadened from the descriptive to the analytical by Gramsci (1971), who used it to emphasise Fordism's hegemonic reach; the "sheer breadth of vision that comprises Fordism" thus also 
attempted to account for the economic, cultural and political structures of advanced capitalism (Hall, Held and McGrew, 1992: 185).

Jessop (1992), working from the regulation approach,' used four levels of analysis to explain Fordism. First, Fordism involved a distinct type of capitalist labour process, that is, the technological and social aspects of production, as outlined in the previous paragraph. Secondly, the accumulation regime of Fordism, that is, the macro-economic regime that sustains expanded reproduction, was based upon a "virtuous circle of growth based on mass production and mass consumption" (Jessop, 1992: 47). The third level of analysis is the mode of regulation, that is, the emergent network of norms and institutions which sustain, guide and reproduce the accumulation regime, aiming to ensure a match between production and consumption. In Fordism, wage levels, based upon the semi-skilled worker, were linked to productivity and wage rises were passed on to all sectors. There was a détente between unions and management. Enterprises, which tended to be large and monopolistic, gained their profits from improvements in productivity, economies of scale and cost-plus pricing. The banking and credit system were nationally-based. High levels of mass consumption were stimulated by mass advertising and retailing. Aggregate demand and mass consumption norms were managed and maintained by a Keynesian welfare state. The 'social security' offered by this state was predicated on full employment and the "family wage', which both allowed and reinforced women's place in the 'reserve army of labour' (Shields, 1996). The final level of analysis is the mode of societalization, that is, the pattern of institutional integration and social cohesion. Fordism was thus predicated on a 'wage' society, with individualised consumption of standardised commodities: 'the American way'. There was an acceptance/expectation of the role of the state in the provision of activities necessary for the "social reproduction of labour-power" (Jessop, 1992: 51).

\section{The Crisis of Fordism}

Altvater (1992) argued that the dynamics of accumulation in the post-war years had three principal causes: the complementarity of productivity growth and demand growth, high capital productivity, and the unevenness of development across nations, which facilitated the explosive growth of world trade via the "opportunities of backwardness' (Maddison, 1987). The "converging development of productivity", however, resulted in the "tendential equalization of productivity levels in the industrialized world" (Altvater, 1992: 26). This "catchup' process eliminated the 'wind-fall' profits that had so benefited the USA and thus precipitated the crisis of Fordism.

Using Jessop's four levels of analysis, then, first, productivity gains made via the Fordist labour process were exhausted. Secondly, the well-oiled virtuous circle of mass production and mass consumption ground to a halt as markets became saturated and national economies were increasingly exposed to international forces. Thirdly, the limits of the Fordist mode of regulation became apparent. The 'family wage' was displaced by the 'family income unit', as earning power dropped and women began to enter the paid workforce in greater numbers, both by choice and through necessity (Shields, 1996). Workers' organisations flexed their muscles; the ideal-type Fordist firm proved unequal to the challenge of improving productivity; the Keynesian welfare state came under increasing pressure; and the national state was less able to influence global finance flows. Finally, there was resistance to the Fordist mode of societalization, with changing consumption patterns; a rejection of standardised products and services; and a rise in new social movements (Elam, 1994; Jessop, 1992).

\section{The 'Working Out' of the Crisis: Post-Fordism?}

Attempts to understand both the crisis of Fordism, and the nature and extent of the changes that the crisis may have engendered, are bundled together (with not a little discomfort, in many cases) under the all-encompassing umbrella of the 'post-Fordist debate'. A key aspect of this debate is whether the changes of recent decades represent modifications to Fordism, that is, are neo-Fordist, or are qualitatively different from Fordism, that is, are postFordist: "the key question is whether or not a fundamental transformation, or paradigm shift, can truly be said to have occurred in the nature of contemporary capitalism, the employment relationship and waged labour itself" (Lloyd and Payne, 2002: 366).

Turning again to Jessop's (1992) levels of analysis, the post-Fordist labour process would be based on flexible production processes (flexible technology, work organisation and workforce), with a heavy emphasis on information technology as the source of flexibility and the driver of innovation. The accumulation regime would balance the flexibility of production with growing productivity based on economies of scope and increased demand (on a global scale) for niche products by wellpaid, multi-skilled workers. The mode of regulation would "involve commitment to supply-side innovation and flexibility in each of the main areas of regulation": a differentiated and flexible labour market, both within and between countries; 'flatter', more responsive enterprises; an emphasis on contractual relationships; internationalisation of credit; and a refocusing of the state from managing demand to stimulating the supply-side (Jessop, 1992: 63). Clearly, none of the above can be seen as 'finished products', and the patchy and incomplete nature of what may be a tendential move to post-Fordism makes an attempt to describe an accompanying mode of societalization difficult (Jessop, 1992). Some possible characteristics of that mode, however, include a "hyperdifferentiated emphasis on difference, individuation and the reflexive construction of taste" (Waters, 2001: 215).

\section{Fordism to Post-Fordism: Workforce Planning to Workforce Development}

Many aspects of the above (regardless of the fact that such changes may be tentative, partial or potential rather than actual) have both a direct and implicit impact on 
ideas about how an appropriately sized and skilled workforce may be generated.

Under an ideal type Fordist regime, for example, factors such as relatively stable occupational classifications, full employment, the notion of a 'job for life' and a societal acceptance of a certain level of centralised state control meant that workforce or manpower 'planning' was at least a possibility. This is not to say, of course that such planning was successful, merely that conditions were such that it could be attempted.

Consideration of the impacts of the transition to a PostFordist society, however, make it clear that centralised, linear 'planning'. which attempts to match a 'supply' of young people leaving the education system with a predetermined and pre-existing 'demand' is no longer viable. For example, at the labour process level, technological 'flexibility' may require workers who are adaptable and able to 'learn to learn', and who are equipped with portable skills. The 'flat' or 'lean' enterprise may require leadership and planning skills from a wider range of workers. Conversely. it may also mean the collapse of 'job ladders' via the loss of middle-management positions, and work intensification as tasks are devolved (Shields. 1996). An emphasis on formalised contractual relations may mean, at the individual level, that the obligation to train previously inculcated by socialisation is supplanted by externally-imposed dictates. The mode of socictalization may impact on how young people regard various occupations and how they make their career choices. Therefore, if there is to be any ability to shape the current, or anticipate the future workforce, the organic, systemic concept of Workforce Development is more likely to succeed.

Some of the above considerations are drawn to together in Table 2 .

\section{Workforce Development in the Health and Disability Sector}

The impact of these changes has been noted in the health sector. Anne Roche (2001), in the context of the Australian alcohol and other drugs field, describes the dramatic changes in that field over the previous one to two decades, and argues that these have resulted in the need for equally significant changes for the workforce: 'a major paradigm shift is required' away from education and training toward the broad, comprehensive and multifaceted focus' of Workforce Development (2001: 5$6)$.

Kennedy and Moore (2001) introduce the idea of systems thinking to their analysis of public health workforce development. They suggest three components to public health practice: the work, the worker and the work setting, and examine the relationships and interdependencies between each of these (Kennedy and Moore, 2001). Roche (2001) also emphasises that one of the key elements of Workforce Development is the shift to 'systems thinking'. Her analysis examines levels of Workforce Development, as seen in Table 3.

Table 2: Ways of thinking about the workforce.

\section{THE FORDIST WORLD}

Education and training At start of working life

Occupational changes Relatively stable occupations

'Job for life"

Work practices $\quad$ Geographically stable workforce

Economies of scale

Economic background

Family wage

WORKFORCE

Mass production and mass consumption

Political background Keynesian welfare state; national focus

\section{THE POST-FORDIST WORLD}

Education and training

Occupational changes

Work practices

Economic background

Lifelong learning

Flexible occupations: creation, metamorphosis and disappearance

Mobile workforce

Economies of scope; niche products

Family income unit

Differentiated and flexible labour market

Deregulated and market-driven

Political background

Neo-liberal; contractual relationships; global

focus 
Table 3: Levels of workforce development (Roche, 2001: 7).

\begin{tabular}{|l|l|l|}
\hline Level & Descriptor & Examples \\
\hline $\begin{array}{l}\text { Level I: } \\
\text { Systems }\end{array}$ & $\begin{array}{l}\text { Workforce development aims to improve the } \\
\text { functioning of the entire AOD workforce through } \\
\text { addressing the systems and structures that shape } \\
\text { it. While it includes activities that impact on } \\
\text { individuals, its focus is much broader. It involves } \\
\text { creating environments and systems that support } \\
\text { the full range of workforce development } \\
\text { strategies. }\end{array}$ & $\begin{array}{l}\text { Examples of systems and structural } \\
\text { factors include: } \\
\text { - legislation } \\
\text { - policy } \\
\text { - funding } \\
\text { - recruitment and retention } \\
\text { - resources } \\
\text { - support mechanisms } \\
\text { - incentives. }\end{array}$ \\
\hline $\begin{array}{l}\text { Level II: } \\
\text { Current Workers }\end{array}$ & $\begin{array}{l}\text { At the individual level, workforce development } \\
\text { encompasses methods of improving individual } \\
\text { professional functioning. It means ensuring that } \\
\text { opportunities to develop individual skills, } \\
\text { knowledge and attitudes are of high quality, } \\
\text { effective and well utilised. }\end{array}$ & $\begin{array}{l}\text { This can include: } \\
\text { - formal education } \\
\text { - training } \\
\text { - workplace training }\end{array}$ \\
\hline - mentoring \\
Level III:
\end{tabular}

\section{The New Zealand Context}

In New Zealand, the concept of Workforce Development began to be discussed in the Health and Disability sector from about 2000. The Health Workforce Advisory Group began to promote the concept in its 2002 report, The New Zealand Health Workforce: Framing Future Directions Discussion Document (NZIER, 2005). In the same year, Hornblow et al (2002) argued that:

Workforce development has again become an important part of health policy: in New Zealand and internationally: Earlier attempts at workforce planning had been directed primarily towards estimating the numbers required in specific disciplines and sub-disciplines. This was confounded and somewhat discredited by the difficulties of prediction. given the variable impact of a range of factors, including workforce mobility, advancing technology: increasing impact of globalisation, and changing societal and professional expectations. The conceptual shift from workforce planning to workforce development is characterized by a greater focus on how health practitioners can be enabled and empowered to best meet health needs, in a supportive environment, with available resources (Hornblow et al. 2002).

Some definitions of Workforce Development from the New Zealand health and disability sector include: ...any initiatives that influence entry to and exit from the sector, movement within the sector, education, training, skills, attitudes, rewards and the associated infrastructure (Health Funding Authority: 2000).

...to recruit, train employ, deploy and retain a health and disability workforce appropriate to meet the diverse needs of all New Zealanders in the short. medium and long term (Health Workforce Advisory Committee, 2003).

...the ultimate goal of workforce development in the mental health and addiction sector is to ensure that we have the right mental health and addiction practitioners and staff in the right place, at the right time, to treat, support and care for the users of mental health and addiction services (Ministry of Health, 2005: 3).

...development of workforce capability and capacity to satisfy future service demand (Ministry of Health, 2006).

The shift to the concept of Workforce Development and the systems thinking underpinning the concept is clear in the Ministry of Health's National Mental Health (Alcohol and Other Drugs) Workforce Development Framework (2002). This document pulled together significant amounts of prior work into a conceptual scheme or framework, as shown in Figure 1. This framework has been adopted widely across the Health and Disability 
sector and is the basis for a variety of Workforce Development reports.

Figure 1: The five strategic imperatives for mental health workforce development (Ministry of Health, 2002: 16).

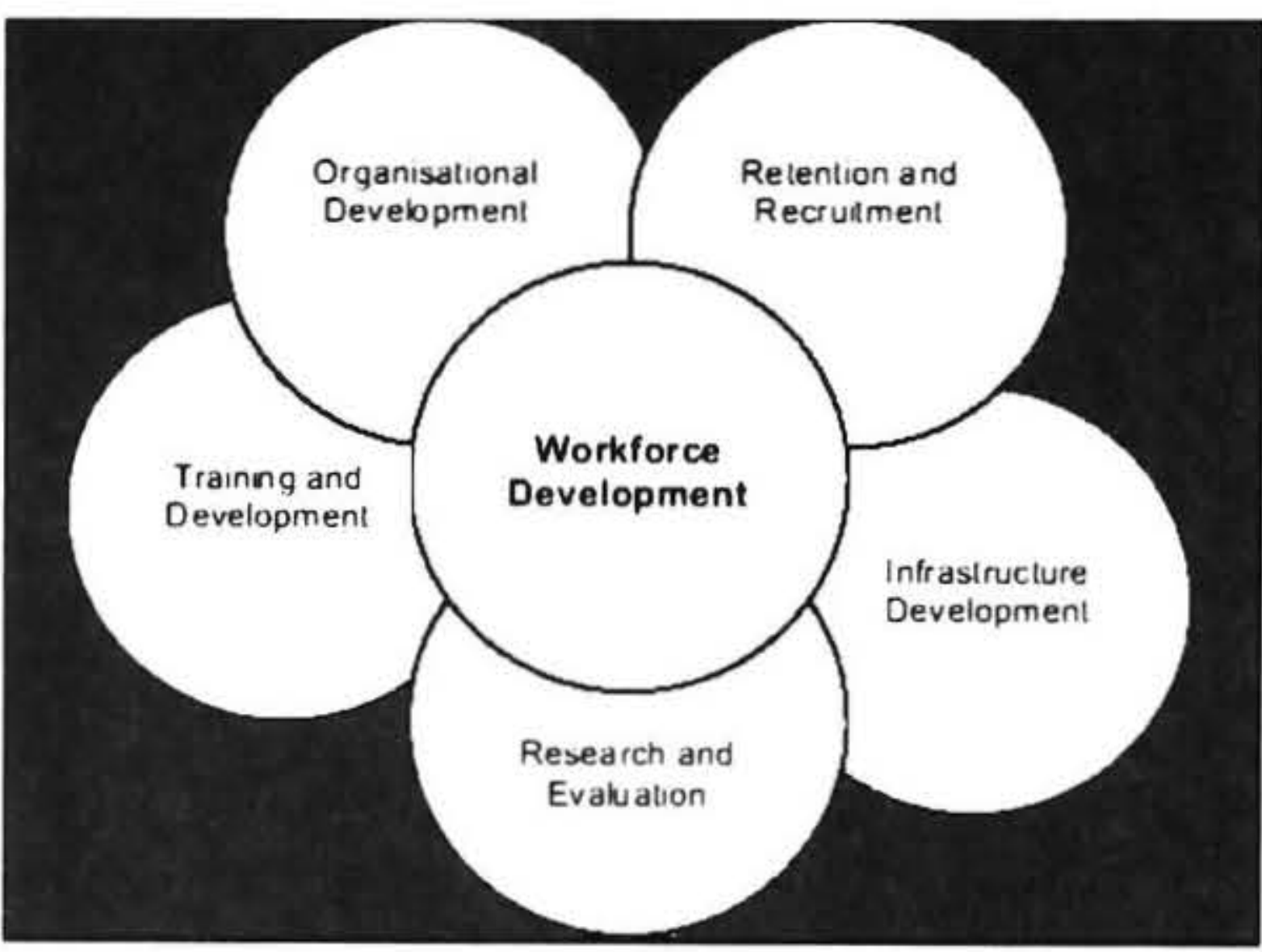

This framework is notable for the breadth of activities it acknowledges as impacting on Workforce Development. Of particular interest are the concepts of organisational and infrastructure development. There is a growing emphasis on the importance of the demand side of skill formation (Murray, 2004). The way in which a workforce is 'developed does not depend only on the supply of workers generated, but on how those workers, and their skills, are acknowledged, recompensed, deployed, trained and retained within the workplace. As Keep (2002) argues:

Rather than a training problem. what we might he faced with. at least in certain parts of the economy: is a problem with product market strategies, work organisation, joh design. and therefore demand for and usage of skill (Keep. 2002: $46.8)$

No matter how Workforce Development is conceived in the health and disability sector, there is little doubt that there has been a plethora of activity carried out under that umbrella. The following are some of the various reports from recent years:

- Pacific Health and Disability Workforce Development Plan. Ministry of Health $(\mathrm{MoH})$, December 2004,

- Future Workforce 2005-20I0, DHBNZ, August 2005 .

- Public Health Workforce Development Plan, $\mathrm{MoH}$, October 2005 ,

- Tauawhita te Wero, Embracing the Challenge: National mental health and addiction workforce development plan 2006-2009. December 2005.
- Kia Puawai Te Ararau, Maori Mental Health Workforce Development Strategic Plan 20062010, January 2006,

- Asian Mental Health Workforce Development Phase One: Feasibility Project, March 2006,

- Raranga Tupuake, Maori Health Workforce Development Plan 2006, April 2006,

- Health Workforce Development: An Overview, $\mathrm{MoH}$, April 2006,

- Health and Disability Sector NGO Workforce Development, June 2006,

- Te Awhiti, National Mental Health and Addictions Workforce Development Plan for, and in support of, NGOs 2006-2009, July 2006,

- The Non-regulated Workforce in the Health and Disability Sector, DHBNZ, September 2006,

- Care and Support in the Community Setting, HWAC, October 2006.

Each of the 21 District Health Boards (DHB) ${ }^{2}$ also has its own workforce development plan, contained within its District Annual Plan, and a good example of the multiplicity of understandings around Workforce Development may gained from examining these. Some DHB annual plans have a separate dedicated Workforce Development section; in others Workforce Development is discussed as part of a broader topic - 'infrastructure' or 'sustainability', for example. Some DHB plans include Workforce Development in either their Human Resources, Education and Training, or Employment/Industrial Relations sections; others place those sections under Workforce Development. Finally, some DHBs discuss sectoral workforce issues, for example, Māori, as part of broader workforce development, while others discuss workforce development in terms of servicing separate sectors. Again, this indicates differences in notions of the development of the existing workforce compared with the development of a future or specific workforce.

While some of this analysis may be dismissed as semantics or formatting, I suspect that a deeper examination would uncover real and meaningful differences of attitude, emphasis and action between the various DHBs, fueled by their conception of Workforce Development.

\section{Conclusion}

My purpose in writing this paper is to draw attention to a term that, although relatively common in usage, is largely unexamined. While it is useful to have a term that encompasses many activities, there are three dangers inherent in what I hope to have shown as the ambiguity surrounding 'workforce development'. First, the lack of 
clarity about the term means that there is a great deal of scope for individuals, organisations and government agencies to be at cross-purposes when they talk about workforce development. Second, I suspect that in many cases, reporting on 'workforce development' activities acts as a substitute for actually carrying out the activity. Finally, I would suggest that although the term implies that the demand side is being considered, in reality much of the focus remains on the relatively easier supply side issues. Continuing skill shortages, gaps and mismatches in many of the areas where workforce development abounds lead me to believe that without a more rigorous debate about the concept, it is no more likely to succeed than its 'workforce planning' predecessor.

\section{Future Research}

This has been only a very cursory examination of the topic of workforce development. A thorough literature review would be essential to trace more exactly the genesis of the term and its roots in systems thinking. It could also be interesting to undertake some discourse analysis of the ways in which 'workforce development' is used, and by whom. A stock take of various initiatives and their long term outcomes would also be useful at a practical level.

\section{Notes}

1 The regulation approach was pioneered in France in the 1970s, drawing on the work of (amongst others) Aglietta (1979), Coriat (1979), Boyer (1986) and Lipietz (1985; 1987) (Amin, 1994). The approach emerged as Marxist political economists, influenced by Gramsci, shifted their attention from an emphasis on value theory to a greater concern with the social forms of capital (Elam, 1994)

2 District Health Boards (DHBs) are responsible for providing, or funding the provision of, health and disability services in their district. There are 21 DHBs in New Zealand and they have existed since 1 January 2001 when the New Zealand Public Health and Disability Act 2000 came into force (www.moh.govt.nz/districthealthboards).

\section{References}

Aglietta, M. (1979). A Theory of Capitalist Regulation: The US Experience. London: New Left Books.

Altvater, E. (1992). Fordist and post-Fordist international division of labour and monetary regimes. In Storper, M. and Scott, A. (eds), Pathways to Industrialization and Regional Development. London: Routledge.

Amin, A. (1994). Post-Fordism: Models, fantasies and phantoms of transition. In Amin, A. (ed.), PostFordism: A Reader. Oxford: Blackwell Publishers.
Barton, J., Emery, M., Flood, R., Selsky, J. and Wolstenholme, E. (2004). A maturing of systems thinking? Evidence from three perspectives. Systemic Practice and Action Research, 17(1), 335.

Boyer, R. (1986). La Théorie de la Régulation: Une Analyse Critique. Paris: La Découverte.

Boyer, R. and Drache, D. (1996). States Against Markets: The Limits of Globalization. London: Routledge.

Churchman, C.W. (1968). The Systems Approach. New York: Delta.

Coriat, B. (1979). L'atelier et le Chronomètre. Paris: Christian Bourgeois.

Elam, M. (1994). Puzzling out the post-Fordist debate. In Amin, A. (ed.), Post-Fordism: A Reader. Oxford: Blackwell Publishers.

Gramsci, A. (1971). Selections from the Prison Notebooks. London: Lawrence and Wishart.

Hall, S., Held, D. and McGrew, T. (1992). Modernity and its Futures. United Kingdom: Polity Press.

Health Funding Authority (2000). Tututahitia te Wero, Meeting the Challenges: Mental Health Workforce Development Plan 2000-2005. Christchurch: Health Funding Authority.

Health Workforce Advisory Committee (HWAC) (2003). The New Zealand Health Workforce Future Directions - Recommendations to the Minister of Health 2003. Wellington: HWAC.

Hornblow, A. et al. (2002). Workforce development: a quick fix or a collaborative process? Journal of the New Zealand Medical Association, 115, 1156.

Jacobs, R., and Hawley, J. (In press, 2005). Emergence of workforce development: Definition, conceptual boundaries, and future perspectives. In MacLean, R.and Wilson, D. (eds), International Handbook of Technical and Vocational Education and Training. Bonn, Germany: UNESCO-UNEVOC.

Jessop, B. (1992). Fordism and post-Fordism: A critical reformulation. In Scott, A. and Storper, M. (eds). Pathways to Regionalism and Industrial Development. London: Routledge.

Jessop, B. (2000a). Good Governance and the Urban Question: On Managing the Contradictions of Neo-Liheralism [Website]. Lancaster University. Retrieved 20 September, 2001, www.comp.lancs .ac.uk/sociology/soc075rj.html

Keep, E. (2002). The English vocational education and training debate - fragile 'technologies' or opening the 'black box': Two competing visions of where 
we go next. Journal of Education and Work, 15(4), 457-479.

Kennedy, V.C. and Moore, F.I. (2001). A systems approach to public health workforce development. Journal of Public Health Management Practice, 4, 17-22.

Lipietz, A. (1985). The Enchanted World: Inflation, Credit and the World Crisis. London: Verso.

Lloyd, C. and Payne, J. (2002). Developing a political economy of skill. Journal of Education and Work, 15(4), pp.365-390.

Maddison, A. (1987). Growth and slowdown in advanced capitalist economies: Techniques of quantitative assessment. Journal of Economic Literature, 25, 649-698.

Ministry of Health (2002). National Mental Health (Alcohol and Other Drugs) Workforce Development Framework. Wellington: Ministry of Health.

Ministry of Health (2005). Tanawhitia te Wero Embracing the Challenge: National mental health and addiction workforce development plan 20062009. Wellington: Ministry of Health.

Ministry of Health (2006). Health Workforce Development: An Overview: Wellington: Ministry of Health.

Murray, N. (2004). Who Gets Their Hands 'Dirty' in the Knowledge Societr? Training for the Skilled Trades in New Zealand. Unpublished doctoral thesis. Lincoln: Lincoln University.
NZIER (2005). Approach to Health Workforce Forecasting: Discussion Paper Prepared for District Health Boards NZ. Wellington: NZIER

Roche, A.M. (2001). What is this thing called workforce development? In Roche, A.M. and McDonald, J. (eds.), Systems, Settings, People: Workforce Development Challenges for the Alcohol and Other Drugs Field, Adelaide: National Centre for Education and Training on Addiction (NCETA).

Roche, A.M. (2002). Workforce Development Issues in the AOD Field: A Briefing Paper for the InterGovernmental Committee on Drugs, Adelaide: National Centre for Education and Training on Addiction

Senge, P. (1990). The Fifth Discipline. New York: Doubleday.

Shields, J. (1996). Flexible work, labour market polarization, and the politics of skills training and enhancement. In Dunk, T., McBride S. and Nelsen, R. (eds), The Training Trap: Ideology, Training and the Labour Market. Winnipeg: Society for Socialist Studies.

Waters, M. (2001). Globalization (2nd ed.). London: Routledge.

\section{Author}

Nicky Murray

Workforce Development and Research

CareerForce

P.O. Box 25-255

Christchurch

NickyM@cssito.org.nz 